\title{
The Importance of Risk MANAgement
}

Andrew L. T. Sheng*

I have a terribly difficult task, because I have very little to add after such excellent presentations by three wise men, Stanley Fischer, whom I worked for in the World Bank, Jeffrey Goldstein of the World Bank, and Professor Yoshitomi. What I would like to do is to give you a slightly unorthodox view of financial crisis and to think laterally about why we need national risk management to prevent the next crisis.

\section{The IDENTIFICATION OF RISK}

I start with the troubling thought that mainstream development economics over the last 50 years has been obsessed with achieving high growth, since growth was associated with development and the eradication of poverty. But there was no clear realization that high growth can be achieved only at high risk. Developing countries really need to think very carefully about how to manage the risks of growth on a national basis rather than on a sectoral basis.

Basically speaking, the 1970s sovereign debt crisis arose because governments bet on promoting growth through huge domestic and external borrowing. After that crisis was resolved through IMF restraints on fiscal imprudence, the crises of the 1980s and the Asian crisis erupted because the private sector took huge risks through excessive leverage. It was widely believed that as long as the public sector did not run large deficits, the engine of national growth through the private sector would be self-stabilizing. Of course, that turned out to be wrong. Private sector mistakes can destabilize economies as much as public policy errors.

${ }^{*}$ Chairman, Securities \& Futures Commission, Hong Kong. 
Consequently, what we really need to focus on is the need to manage sectoral risks, which add up to national risks. And national risks add up to global risks. In essence, financial crisis-which covers banking crisis, currency crisis, and debt crisis-can really be reduced to two fundamental types: either a solvency crisis or a liquidity crisis. Now solvency crises can destroy individual companies, financial institutions, or whole economic sectors through the liquidation mechanism, but in practice, you cannot liquidate a sovereign nation. Countries generally face liquidity crises, even though some of them could be technically insolvent. So the question is, how do we prevent financial crisis through national risk management?

\section{Risk Management and the Financial Architecture}

Former IMF Managing Director Michel Camdessus said in a recent speech that when he was dealing with the international financial architecture, he realized that he was in reality a fireman. It is difficult dealing with architectural issues when you are fire fighting. What I interpreted from his comment was that we are dealing with the process of change and how we cope with change. It reminded me of the key lesson of my study in the early 1990s, when I worked at the World Bank, surveying the lessons of banking crises in the 1980s. The lesson was this: Financial crisis is an event but bank restructuring is a process.

Financial markets involve many different processes-trading, clearing, settlement, and payment. Different institutions run these processes, and they behave very differently under different circumstances, especially in normal times and during a crisis. For example, fair value accounting is all about accounting, under normal market conditions. But we all know that fair value accounting does not work at all during a crisis. During a crisis, there is no fair market value, since assets may have to be sold at liquidation prices in order to obtain liquidity.

What I am saying is that our present financial structure is fundamentally designed for normal events, whereby banks behave normally with a banking book that is priced for normal times. The process that takes care of the spike in interest rates is the lender of last resort function of the central bank. In a solvency or liquidity crisis-the spike-the bankers run to the central bank for liquidity. Without liquidity, interest rates rise further, and at excessively high interest rates, all banking books could become insolvent when assets are marked to market. The market panics when it realizes that the depository of public savings, the banking system, may be insolvent.

Consequently, the Bagehot dictum that central banks should lend freely against collateral during a crisis is the process by which central banks provide liquidity for the market to restore normal conditions as soon as possible. During these times, a central banker is a market 
bookmaker, providing liquidity at a price when no one else is willing to provide liquidity. In a closed economy, a central bank can print money to provide domestic liquidity. But in an open, global market environment, the ball game is very different for the lender of last resort.

\section{The Need to Strengthen Our Financial Networks}

Instead of waxing about global financial architecture, we should think in process or engineering terms. In technical terminology, financial systems or markets are essentially networks. We have securities market networks, banking market networks, insurance market networks, trading and commercial networks, all linked through hubs of exchanges or clearing houses or through electronic communication network (ECN) "crossing" of trades.

The trouble with this architecture is that it evolved through loose alliances and mergers, and no one actually sat down to design the global network. As we know, networks have both positive and negative externalities. Networks create leverage whereby one participant can exchange and use another participant's resources. Wide networks allow complex multi-modal relationships to be entered into, in which leverage can be many tiered. ${ }^{1}$ The unfortunate part is that if one component of that leverage chain fails, the whole network may fail. In other words, leveraging actually accentuates or multiplies the interdependency of markets through the global market network.

Today, the global financial market has evolved through a patchwork of various local area networks linking together banking, securities, insurance, asset management, and real trades. The flaw of any patchwork of networks is that it is only as robust as its weakest link. And the trouble is that in the global area network, local networks were not traditionally designed to take global shocks. Most domestic financial systems have been designed on the basis that the central bank takes care of the spike, which typically originates domestically.

Once domestic financial systems got integrated to the global economy through trade and financial liberalization, domestic systems became vulnerable to external shocks. In Asia, US $\$ 300$ billion arrived in the form of capital inflows to the four crisis economies in the three years prior to the crisis, and roughly US\$200 billion was withdrawn in the two years post-crisis, mostly in bank credit. This tidal wave of foreign currency flows overwhelmed whatever central bank reserves were available to defend fixed exchange rates.

An interesting lesson from bank failures in the 1980s was that the

${ }^{1}$ In other words, derivatives enable a single capital base to support multiple leveraging with many counterparties. 
worst part of the crisis came when you had to rescue the rescuer. If you look at every single major banking crisis in the 1980s, beginning with the U.S. S\&L crisis, it was not the banks failing that first forced the politicians to take action. It was either the deposit insurance scheme or the central bank becoming insolvent that forced the politicians to wake up.

Consequently, the resilience of the domestic network design to stress is very important to the global architecture. How do we design the local area networks that are our domestic financial systems to become resilient to take global shocks? Using a simple example, the Long-Term Capital Management (LTCM) value-at-risk model was designed to operate convergence trading when markets historically moved a maximum of four standard deviations. The Russian crisis caused the markets to move 15 standard deviations, so LTCM went bust. It was the same story with the Asian crisis economies. Those financial systems were essentially designed in the 1960s and 1970s for domestic savings mobilization purposes. The authorities never dreamt that their systems would be subject to such exchange rate or capital flow shocks.

\section{RisK MANAGEMENT}

Let me now turn to the issues of valuation, liquidity, and risk management. As I said earlier, the banking loan book is normally based upon historical cost value. Banks now mark their trading book using market prices, typically using the mean of bid-ask spreads of known prices trading under normal conditions. However, as LTCM found out during the Russian crisis, there was no "fair value" during the financial crisis, when everybody went for cover. Consequently, fair market prices are all dependent upon market liquidity and cash flows. But during a financial crisis, liquidity dries up if there is no buyer of last resort. In providing liquidity to the market, the central bank has become the buyer of last resort. And if no one acts in that role during a crisis, once the liquidity begins to dry up and there is no price at which you can obtain liquidity, even the most solvent of economies can be overwhelmed. This is what happened to Korea during the Asian crisis.

\section{CONCLUSIONS}

The first conclusion I draw from all this is that we now have a global problem, in which there is no official lender of last resort or liquidity provider of last resort when global markets begin to panic for one reason or another. The major shareholders, for moral hazard reasons, will not permit the IMF to fulfill that function. The logical answer to all this is that domestic financial systems will therefore have to be designed to take global shocks at higher levels than before.

The second conclusion that I draw is that we need to look at risks 
much more carefully than before. Using VAR models, we glibly assumed that market risk can be differentiated from credit risk. But as the LTCM crisis has shown vividly, during the financial crisis you cannot distinguish a market risk from a credit risk. In essence, a liquidity crisis transmits very quickly across the global network to become a solvency crisis.

Taken together, both conclusions suggest that we really need to rethink our global architecture and the way we manage our risks domestically. We have to worry about how risks emerge in different parts of our economy and our financial markets, how systemic risks interplay between the different components, and how such risks interact with external forces. We need to identify these sectoral, national, and global risks, and then we need to hedge or shift these risks. Small economies and domestic financial systems cannot depend on the international architecture to handle these global risks.

Seen from this angle of national risk management, let me try and answer the question that seems to stand out during the Asian crisis: Why is it that economies with high central bank reserves and lower debt survived the shocks better? In hindsight, the answer is very simple. The Modigliani-Miller theorem tells us that asset diversification reduces risks. But these assets must be negatively correlated with each other. For these small banks in small economies that cannot diversify their risks, the one asset that is 100 percent negatively correlated with their domestic risks is foreign exchange reserves. And I am not talking about gross reserves, it has to be net reserves. Again, as the LTCM crisis showed, during a financial crisis, it is not net liabilities that matter, but gross liabilities. Consequently, the central bank must have deep net foreign exchange reserves to be able to absorb all these global shocks on the domestic economy.

To conclude, we really now need to think about how we manage national risks in a volatile global market. And the only way you can manage these risks is through good information. Unfortunately, we still have very poor information to manage our risks. Why do I say this? We base all our statistics on accounting information. As we heard earlier in this conference, we have poor accounting either because we do not apply international accounting standards, or because the standards are not properly enforced or implemented. How many banks and state-owned enterprises in this world are operating on the basis that they are solvent in accounting terms, but are economically insolvent, if their balance sheets are properly marked to market? I call these insolvent banks and enterprises "zombies." Since their losses are quasi-fiscal deficits, and they are still operating actively in many markets, how can the rest of the market price their risks correctly? If we are not pricing and managing these credit and market risks correctly, then many of these zombies must be heading for the next crisis. 
Let me give you a very simple example using the restructuring of the banking system in Asia. I have now worked in the banking systems in Asia for the past 30 years. Over those 30 years, banks in Asia have had at least three cycles of bank crises, with levels of nonperforming loans peaking at around 15 percent in the 1970s and 1980s, to as much as 50 percent of total bank loans this time round. What has been done in Asia is to recapitalize all these banks at huge public cost. But guess what the average net bank spreads are in Asia today? Roughly 1 percent after administrative costs. How can a net bank spread of 1 percent cover an average statistically of about 10 to 15 percent in nonperforming loan provisions over 30 years? The answer is that the banks will again fail, if spreads do not adequately cover loan loss provisions.

Clearly, if bank intermediation continues in Asia along the old way with narrow spreads, some banks in Asia will have to be recapitalized once again. If banks still price their risks depending upon central banks to bail them out, then we have not eliminated a key moral hazard. That is why I think we really need to build much deeper securities markets and bond markets in Asia to enable the economies, the sectors, and the enterprises to manage and diversify their risks properly.

On top of that, we need the most fundamental building brick and the real foundation of efficient markets, which is high-quality and timely information. As long as we do not have timely and reliable information, we have terribly shaky foundations, where a financial system may still collapse the next time global shocks arrive. As we all know, no two financial crises are the same. And you can bet your bottom dollar, there will be another financial crisis. 